\title{
Excreção fracionada de eletrólitos e acidúria paradoxal em vacas leiteiras com deslocamento de abomaso à esquerda
}

João Henrique Perotta;, Júlio Augusto Naylor Lisbôa, Priscilla Fajardo Valente Pereira, Rüdiger Daniel Ollhoff, Karina Keller Marques da Costa Faliban, Ivan Roque de Barros Filho

Departamento de Medicina Veterinária, Universidade Federal do Paraná (UFPR), Curitiba, PR, Brasil

*Autor correspondente

e-mail: perotta@ufpr.br

\section{Resumo}

A excreção fracionada de eletrólitos é utilizada para avaliar a função renal e auxiliar na interpretação de desequilíbrios ácido-base e eletrolíticos. 0 deslocamento de abomaso à esquerda é uma doença comum em rebanhos leiteiros de alta produção, e uma das manifestações clínicas desta doença é a alcalose hipoclorêmica e hipocalêmica, em decorrência do refluxo de cloro abomasal para o rúmen, acúmulo de bicarbonato no sangue e aumento da excreção de potássio. Geralmente, o pH urinário é regulado pelo $\mathrm{pH}$ sanguíneo, visto que os rins preservam o pH plasmático normal. Desta maneira, vacas com deslocamento de abomaso deveriam apresentar urina alcalina, entretanto, uma acidúria paradoxal se desenvolve nestes casos em decorrência do aumento da excreção de hidrogênio. Porém, há poucas informações sobre excreção fracionada em vacas com deslocamento de abomaso e o efeito da correção cirúrgica sobre a dinâmica excretória dos íons. 0 objetivo desse trabalho foi mensurar a excreção fracionada de sódio, potássio e cloro e o pH urinário em vacas com deslocamento de abomaso à esquerda antes e depois da correção cirúrgica. Para isso, foram coletadas amostras de sangue e urina de 30 vacas antes, 24, 48 e $72 \mathrm{~h}$ após o procedimento cirúrgico. As vacas foram divididas em dois grupos: grupo G1, com 15 animais, os quais foram tratados com abomasopexia por laparoscopia; e grupo G2, com 15 animais, os quais foram tratados com abomasopexia por laparotomia pelo flanco direito. As concentrações de sódio, potássio, cloro e creatinina foram mensuradas no soro e urina. 0 pH urinário e o pH sanguíneo também foram mensurados. Vacas de ambos os grupos apresentaram alcalose metabólica hipocalêmica, porém hipocloremia só foi observada no G2. A concentração plasmática de potássio aumentou significativamente 24,48 e $72 \mathrm{~h}$ após a operação no G1 e 48 e 72h após cirurgia no G2. Não houve diferenças significativas nas excreções fracionadas dos três eletrólitos e do pH urinário entre os tratamentos e momentos. Acidúria paradoxal foi observada somente antes da cirurgia e 24 h após no G1. Não houve interferência da técnica cirúrgica sobre a excreção fracionada 
e concentração plasmática dos eletrólitos. A excreção fracionada mostrou-se ser uma ferramenta valiosa para auxiliar na interpretação e entendimento da alcalose hipoclorêmica e hipocalêmica e na acidúria paradoxal em vacas com deslocamento de abomaso à esquerda. 